\title{
Balancing employee needs, project requirements and organisational priorities in team deployment
}

\section{Abstract}

The "People and Performance" model asserts that performance is a sum of employee Ability, Motivation and Opportunity (AMO). Despite extensive evidence of this peopleperformance link within manufacturing and many service sectors, studies within the construction industry are limited. Thus, a recent research project set out to explore the team deployment strategies of a large construction company with the view of establishing how a balance could be achieved between organisational strategic priorities, operational project requirements and individual employee needs and preferences. The findings suggested that project priorities often took precedence over the delivery of the strategic intentions of the organisation in meeting employees' individual needs. This approach is not sustainable in the long-term because of the negative implications that such a policy had in relation to employee stress and staff turnover. It is suggested that a resourcing structure that takes into account the multiple facets of AMO may provide a more effective approach for balancing organisational strategic priorities, operational project requirements and individual employee needs and preferences more appropriately in the future.

Keywords: human resource management, organizational culture, teams, motivation, case study

Word count: 6,450 


\section{Introduction: the construction industry team}

\section{deployment challenge}

Over the past decade the Strategic Human Resource Management (SHRM) paradigm has evolved as an effective and profitable approach to managing people. It is a widely accepted and adopted approach to personnel recruitment, retention and performance improvement within many public and private sector organisations (Pfeffer, 1994; Huselid, 1995; Mabey et al, 1998; Taylor, 2002; Armstrong and Baron, 2002; Boxall and Purcell, 2003). However, despite the labour-intensive, "people oriented" nature of the construction industry (Druker and White, 1995: 80; Smithers and Walker, 2000: 833) little attention has been paid to SHRM within the sector (Loosemore et al, 2003). In light of staff shortages, increasing client demands and requirements for greater overall efficiency, productivity and cost effectiveness within the industry (Egan, 1998; Strategic Forum for Construction, 2002; CITB, 2003), this paper considers SHRM as a potential route to performance improvement in people related issues in the construction industry. As a basis for analysis it draws upon the "People and Performance" model developed by Boxall and Purcell (2003: 20), which asserts that performance is a sum of employee Ability + Motivation + Opportunity (AMO). These three dimensions can be realised via integrated set of performance-related policies covering recruitment and selection, training and development, career development, communications, employee involvement, teamworking, appraisal, pay, job security, job challenge/ job autonomy and work-life balance (Purcell et al, 2003: ix).

Employee resourcing is the element of SHRM that focuses on the allocation or deployment of human resources within organisations. Due to the project-based nature of construction work, team deployment is the central employee resourcing concern for contracting organisations, but one which represents a challenging task. Firstly, the fluctuations in the economic markets are reflected in considerable variations in the 
number, size and type of projects undertaken by construction organisations over time. The variations in the organisations' workloads cause significant alterations in their staffing needs, both in terms of volume and professional skill profiles. Secondly, since the industry's output is largely non-transportable construction organisations are required to set up temporary organisational structures at dispersed geographical locations. This can cause issues with regards employees' work-life balance. Moreover, the units frequently operate at a distance from central management with a significant and necessary degree of independence. Hence, delegation and empowerment become essential aspects of the management of construction work (Dainty et al, 2002; Nesan and Holt, 2002) and the characteristics of staff allocated to project teams has a crucial effect on organisational/ project performance. Thirdly, the unique requirements of each client necessitate the formation of bespoke teams each time a new project is awarded. In addition, the time available between contract award and the mobilisation of the project is usually extremely limited (Druker et al, 1996: 407). This renders planning for such deployment difficult and requires contractors to maintain a highly mobile and flexible workforce with wide-ranging professional and managerial capabilities.

Understanding the efficacy of this process requires an understanding of the extent to which the current team deployment processes are able to determine the ability of construction teams $(A)$, the motivation of their members $(M)$ and their opportunities with regards to their development and contribution within their organisation (O). However, despite the extensive evidence of the people-performance link within manufacturing and many service sectors (MacDuffie, 1995; Huselid, 1995; Wood and de Menezes, 1998; Hutchinson et al, 2000; Boxall and Purcell, 2003; Marchington et al, 2003), such studies in the construction industry are limited. Consequently, this paper seeks to begin to address this gap by reporting on research which explored employee needs and preferences, project requirements and organisational priorities in team deployment with the view of establishing how a case study organisation could achieve a balance between the organisational strategic priorities, operational project requirements and individual employee needs and preferences within the AMO framework. The discussion is 
organised into five main sections. Firstly, the AMO model is introduced, followed by a description of the research design and methodology. The research findings are then explained within several subsections, which are grouped under the AMO headings (ability, motivation and opportunity). Fourthly, a discussion section explores the applicability of the AMO model to the case data and highlights some of the key issues (in terms of the organisational strengths and weaknesses), and the specific challenges (such as job challenge/ autonomy and work-life balance) that affect their operations. Finally, the conclusions suggest that a structured resourcing framework is required to provide a more effective approach to balancing the organisational strategic priorities, operational project requirements and individual employee needs and preferences.

\section{The people-performance model: Ability, Motivation,} Opportunity (AMO)

Several studies have investigated the crucial people-performance link that SHRM advocates. This has resulted in the development of many models and theories which often build on strategic management concepts, such as the HR bundles and High Commitment Management (HCM) (MacDuffie, 1995); innovative work practices (Ichniowski et al, 1996); resource-based view of the firm and SHRM (Boxall and Steeneveld, 1999); and High Performance Work Systems (HPWSs) (Boxall and Purcell, 2003). There seems to be little agreement in terminology and application. HPWSs are generally considered the American equivalent to British HCM (Huselid, 1995; Wood and de Menezes, 1998; Purcell, 1999; Hutchinson et al, 2000: 64; Boxall and Purcell, 2003: 92). Despite this, the foundations of much of this research are based on the AMO model. 
The A, M and O within the "People and Performance" model (Boxall and Purcell, 2003)

offer a structure for identifying desirable components for a high performance organisation on the basis that, people perform well when:

- they are able to do so (they can do the job because they possess the necessary knowledge and skills);

- they have the motivation to do so (they will do the job because they want to and are adequately incentivised);

- their work environment provides the necessary support and avenues for expression (for example, functioning technology and opportunity to be heard when problems occur) (Boxall and Purcell, 2003: 20, emphasis in original).

Collectively, rigorous recruitment and selection, together with training and development, increase ability levels. Career development, pay, job security, job challenge/ job autonomy and work-life balance policies in turn enhance motivation. Finally, communications, employee involvement, teamworking and appraisal ensure employees an opportunity to contribute. Thus, the principles of AMO contend that adopted alone any of these practices are unlikely to effect performance (MacDuffie, 1995; Ichniowski et al, 1996; Boxall and Purcell, 2003; Liao, 2005). These are the theoretical propositions which the research used as a basis for analysis in seeking to develop an understanding of the competing priorities in the deployment process.

\section{Research design and methodology}

The people-performance literature draws upon a variety of methodologies and methods in examining the relationship between HR practices and organisational performance using different levels of analysis (Ichniowski et al, 1996). Some studies (such as MacDuffie, 1995; Huselid, 1995; Lähteenmäki et al, 1998; Den Hartog and Verburg, 
2004) conduct large scale surveys with the aim to provide generalisable data. Others base their research on case studies that provide rich insights (for example Boxall and Steeneveld, 1999; Hutchinson et al, 2000; Purcell et al, 2003, Marchington et al, 2003). Both designs have weaknesses. Purcell (1999) and Ichniowski et al (1996) question the utility of large scale surveys on the grounds that single respondents, who may have limited knowledge of what is happening in the workplace, are encouraged to tick a box in relation to a pre-selected easily measurable item. This eliminates the use of surveys where in-depth data is required and instead suggests the use of more interpretative methodologies such as case studies.

Yin (2003: 2) suggests that the distinctive need for case studies arises out of the desire to understand complex social phenomena. Case studies do not seek to produce findings generalisable to populations (Platt, 1988:19; Donmoyer, 2000: 51-52), but rather to expand and generalise theories (Yin, 2003: 10). This is known as analytic generalisation and refers to the process where a previously developed theory is used as a template with which to compare the empirical results of a case study (Yin, 2003: 3133). In other words, case studies produce findings generalisable to theoretical propositions, such as the AMO model. Therefore, and since no prior knowledge of the AMO people-performance link in construction team deployment existed, an inductive methodology was adopted for the case study of employee needs and preferences, project requirements and organisational priorities. This was set within an overall interpretative research framework. Exploratory and semi-structured interviews were conducted with divisional directors (4), HRM staff (4), operational senior managers (7) and employees at all levels (35) of a single case study organisation. These groups of respondents formed embedded units of analysis (see Tables 1-3) within the single case, resulting in embedded case study design. An embedded case study design differs from a holistic design in that attention is given to more than one unit of analysis within the main case (Yin, 2003: 42-43). Here, the case study is about a single organisation (the main unit) but within the case, the three different groups of variables (organisational strategic priorities, operational project requirements and individual employee needs and 
preferences) are considered as separate units of analysis. In addition to the interview data, organisational documentation was collected to establish the formal policy and strategy of the organisation. Collectively, the multiple sets of interview data and organisational documentation ensured 'construct validity', which seeks to establish the correct operational measures for the concepts being studied (Yin, 2003: 34-36). Later checks were also carried out in progress review meetings where selected respondents were invited to evaluate the case study findings (see also 'chain of evidence' below under discussion on reliability.) 'External validity', establishing the domain to which the study's findings are generalised (ibid), came from the well-established People and Performance model AMO (Boxall and Purcell, 2003: 20). Finally, 'reliability', a demonstration that the operations of the case study can be repeated and thus errors and biases in the study are minimised (Yin, 2003: 37), was derived from rigorously tested interview schedules and extensive use of NVivo, a qualitative data analysis software (Bazeley and Richards, 2000), summary statement matrices (Miles and Huberman, 1994) and thematic analysis (Boyatzis, 1998) in analysing the multiple sets of data (Scholz and Tietje, 2002). These techniques helped to maintain an explicit 'chain of evidence' (Yin, 2003: 105). Evidence of the original raw data as well as the coded and processed summary entries used in the final analysis (see Tables 1-3) were held in NVivo, which formed a comprehensive research database including literature references.

This type of research methodology provided the study a comprehensive research strategy (Yin, 2003: 14) and allowed for the complexity of variables involved in team deployment decision-making to be taken into account in the appropriate context (Donmoyer, 2000: 47-50). It provided the means for deepening our understanding of the social as well as organisational processes involved (Mitchell, 2000: 182). In terms of the single case approach in particular, the methodology had the benefits of an in-depth investigation of the individual respondent's views with flexibility and imagination in the analysis of data (Eckstein, 2000: 150-151). The embedded case study design also allowed for the examination of the whole, as well as the operational detail of each sub- 
unit (Yin, 2003: 45). Practically, case study design also proved a cost effective means of gaining access to the subject of study (see Eckstein, 2000: 150-151). As such, the case study organisation selected needed to be typical of a 'large employer' in the UK construction industry in terms of annual turnover and number of employees. Although the case study findings are generalised to theory, this brings the benefit of indicating potential applicability of the theory to other similar organisations (Platt, 1988: 11; Schofield, 2000; Yin, 2003: 41). In terms of the management practices however, an atypical or 'critical' case was sought (Yin, 2003: 40); that is, an organisation known to use the principles of good people management to encourage increases in organisational performance. This is in line with Purcell et al (2003) with the benefits of eliminating null results (Eckstein, 2000; Mitchell, 2000; Yin, 2003: 40) and reporting interesting developments (Platt, 1988: 9). In this manner, the conditions for testing the theory are met and "the single case can represent a significant contribution to knowledge and theory building" (Yin, 2003: 40).

Accordingly, a large contractor with an approximate turnover of $£ 600$ million per annum which operates throughout the UK was selected. The company employs around 2000 staff managed in three regional divisions: North, Midlands and South. The regions contain independent operational divisions and smaller departments, each of which serve a distinct sector of the market (water, rail and highway engineering; commercial development; education, health and housing; industrial works and minor works). These divisions and departments operate as relatively autonomous profit centres within a fairly hierarchical organisational structure. 


\section{The case study findings: AMO analysis of team}

\section{deployment}

In the organisational documentation the company described itself as "A People

Business" with the following statement of values:

"The value and importance we place on the loyalty, commitment and flexibility of our employees in the achievement of organisational goals is central to our culture. We understand the importance of a constructive relationship with our employees, and our human resource policies and practices are designed to support this. In order to effectively engage with our employees, we have placed the management of people at a strategic level within the company, recognising that our people are not simply one of the factors of production but the major source of our competitive advantage..."

This mission statement suggests senior management commitment to good people management practice. The values are operationalised through devolved SHRM responsibilities. The commitment is also apparent in the following analysis and discussion on the variables identified as important in resourcing decision-making. Collectively the employee respondents highlighted 47 factors $^{3}$ that they considered important to be taken into account in managerial resourcing decision-making. The managerial respondents considered both project requirements ${ }^{4}$ and organisational strategic priorities ${ }^{5}$, which resulted in a total of 92 variables. These are presented in Tables $1-3$ in relation to the AMO model ${ }^{1}$ and corresponding HR policies/ practices ${ }^{2}$. Each section progresses through the HR policies/ practices considering the employee, project and organisational factors with the view to establishing the compatibility and/ or conflicts between the units. An overall discussion follows before conclusions as to the applicability of the AMO model to the construction industry. 
The first section, ability, considers recruitment and selection and training and development.

\section{Ability}

[Table 1]

\section{Recruitment and selection}

In terms of recruitment and selection, employees highlighted induction as the key to successful integration of new recruits into the organisation (and project teams). Project level managers indicated no concerns with recruitment and selection. However, managers at the strategic, organisational level shared the employee concern for induction. In addition, senior managers highlighted the need to maintain a healthy balance between their agency and permanent staff ratio. This had increased up to 50:50 at the height of the recruitment peak which resulted from the rapid organisational growth. There were fears that in the long-term this would dilute the strong organisational culture which influenced the company's operational approach. The HR director commented:

"We have always had it difficult to bring people in at the senior level, to bring them into the company culture. It is not an easy thing to do. People grow in our culture and receive the training, then they can develop within the company."

\section{Training and development}

At the employee level there was clearly a concern for training and development activities in support of their job competence. This included specific training courses as well as broader developmental opportunities, organisation-wide graduate development programmes and consideration being given to the type of work and procurement 
methods the organisation focuses on. For example, a procurement method that transfers the responsibility for the supply of labour and materials for subcontractors was said to hinder young engineers' development in restricting the variety of experiences available.

For project managers the crucial variable relating to employee/ team ability was crossproject learning. This emphasises the popularity of on-the-job development in construction. Managers at strategic level shared the employee concern for much of the training and development agenda as well as induction. However, development was discussed in a more systematic HR language. For example, reference was made to training plans as a driver for organisational (and employee) development.

The next section on motivation examines career development, pay, job security, job challenge/ job autonomy and work-life balance issues.

\section{Motivation}

[Table 2]

\section{Career development}

In terms of many aspects of career development, the employee and senior manager's views support a clear two-way understanding of the employee needs and preferences and organisational priorities. For employees this included opportunities for upward progression through promotions and horizontal moves, which allow for diverse experiences. For senior managers career development is achievable within realistic employee aspirations through succession planning which seeks to provide transparent progression opportunities. These were also seen as a good retention tool. Despite the 
overall emphasis on 'traditional' careers, fast track progression was encouraged where exceptional talent was observed.

\section{Pay}

In common with attitudes towards career development, both employee and organisational views were similar in relation to pay, although employees placed more importance on benefits, whereas the organisation focused on contractual arrangements in addition to direct salary. It could be that project requirements did not include pay issues since decision-making is taken at higher level.

\section{Job security}

From the employee point of view, job security was considered important, but only where established in discussion with management. Many highly skilled professional members of staff (who were also in high demand externally) did not believe in long-term commitment but said to hold project duration as the intermediate duration of employment. The recent growth in the construction market had increased many peoples' confidence to move between and within organisations. This resulted in the organisation seeing manageable employee turnover as one of the strategic people management priorities. The senior management team sought to stabilise/ increase the company financial turnover according to market fluctuations through repeat business partnerships and by actively marketing the business. The growth figures for 2000-2004 show that the financial targets were successfully achieved (the company turnover grew from £279 million in 2000 to $£ 687$ million in 2004). In relation to the lack of attention to job security, or staff retention, issues at project level it is worrying to note that this was not seen as one of the key priorities for project management. Clearly project managers form the line management structure at this level and it is their responsibility to ensure strategic HRM aims are achieved. Lack of attention to providing continuity of employment for projectbased staff could therefore greatly compromise the longer term strategic priorities of the 
organisation in encouraging manageable staff turnover and developing succession planning and career progression opportunities. It is this lack of commitment to providing job security at a project management level that could also fuel the employee attitudes with regards to duration of employment.

\section{Job challengel job autonomy}

With regard to job challenge/ job autonomy the employee, project and organisational views show a clear consensus that the principles of empowerment are deeply rooted and understood at all levels of the organisation. This is also confirmed by the organisational statement of values. Furthermore, it is evident that well defined roles and responsibilities were a core requirement for motivated individuals and project teams. Project managers in particular emphasised the need to establish clear boundaries for posts so that employees did not end up pursuing the same objectives. This may have derived from occasions of duplication and resulting conflict/ power struggles, which project managers in charge of a more complex project structures noted. The organisational view was that they sought to enhance job satisfaction and enjoyment by encouraging variety of work via job rotation, which further matched the employee wishes for job enrichment and/ or job enlargement. One of the senior managers linked careers issues and teamworking with job challenge/ autonomy:

"People are not only coming to work to earn a good salary, they also want to satisfy their own personal aspirations in terms of the responsibility they have got and feel a part of the team. It is one of my jobs to try and make people feel they are part of a team... to give them jobs which challenge them and to create a climate and a perception in the company that they can go on..." 


\section{Work-life balance}

Similarly to job challenge/ autonomy, work-life balance featured strongly at all levels.

Employees noted long working hours, weekend work, overtime and holiday allowances as areas in need of attention in terms of balancing work and non-work time. Their formal, written contracts of employment stated that a working week consists of $42^{1 / 2}$ hours per week for site-based personnel and $371 / 2$ for senior office staff. In practice both site-based personnel and senior office staff were found to commit more time to their duties than those recognised by their contracts.

Travel and employee health were also of concern for both individual employees as well as for project management. Both parties recognised that much of this was related to the nature of the industry and to some extent little could be done to reduce the amount of travel required. However, some respondents referred to previous divisional agreements which restricted the potential working radius to 50 miles from the head office base and expressed dissatisfaction with regard to abolishment of such rules. Much of the attention in terms of health concerns was related to travel and the associated potential extension to working hours. Although the company provided allowances for staying away during working weeks where daily travel was considered inappropriate, this was said to negatively effect family relations and in one extreme case resulted in burnout. At the same time, some younger respondents had taken up posts in the organisation particularly because of the opportunities for travel and experience. The project related variables also included staff retention as the positive outcome of successful work-life balance, which links in with the strategic priorities of the organisation: facilitating staff retention through manageable workloads and developing an image of 'employer of choice'. This is in line with the company values, although the achievement the aim seems to depend on the effective communication of opportunities within (and outside) the organisation.

The last section on the findings, opportunity, includes communications, employee involvement, teamwork and appraisal. 


\title{
Opportunity
}

\author{
[Table 3]
}

\section{Communication}

The employee respondents saw communication of project information as well as wider organisational issues as crucial to their opportunity to contribute. The managerial respondents at project level recognised this, but in relation to effective two-way communication, both internally and externally. The absence of controversial and/ or adversarial correspondence in particular was important to project management, whereas the strategic priorities of the organisation highlighted the need for managers to be or become approachable and accessible with short and direct links from site employees through to senior office-based managers. This included the integration of a newly acquired division into the larger organisational structure and culture. Effective communications are often seen as the key to delivering the organisational strategic intent through. Clearly, the mutual importance and attention paid to communications within the case study organisation lays a solid foundation for successful SHRM.

\section{Employee involvement}

As was recognised with the motivational aspects of job challenge/ autonomy, the principles of employee involvement and empowerment were highlighted at all levels (employee, project, organisation). These formed the underlying assumptions of the organisational culture, which were founded upon trust and individualistic management style. In particular, employees had formed close relationships with their divisional managers. The hierarchical organisational structure supported this, although this did hinder the flexible deployment of resources across departments. Project managers 
encouraged empowerment in order to serve operational needs: to solve problems effectively at source within the middle management tiers. The Chief surveyor illustrated this:

"I empower my people... if they are involved in the decision-making process, if you get them to buy into it and they go away thinking they have been involved in it, they will want to implement it..."

However, employees and strategic managers looked towards the higher level issues of recognition of contribution to the organisation from management and colleagues.

\section{Teamwork}

Teamworking was clearly of concern to the employees, and project management:

"The real issue in construction is whether you can form good teams or not. This makes the difference between success and failure. Actually half of your longterm success is in the strength of your team." (Operational manager)

The organisation highlighted partnering as a profitable approach to project delivery, but together with the responsibilities for SHRM, responsibility for team selection and maintenance of relationships within the partners was devolved to divisional operational [project] managers. Overall the employee and project related variables were aligned, albeit with slightly different emphases. The employees naturally highlighted the need for managers to communicate potential project opportunities (including interdepartmental transfers) widely so that they would be able to voice preferences to appropriate decisionmakers and indicated preferences for their existing teams to stay together through redeployment. Instead, managers focused on leadership and problem-solving (for example in having disruptive influences rapidly removed). 


\section{Appraisal}

Finally, performance appraisal was discussed as a feedback mechanism. The views with regard to employee needs and preferences, project requirements and organisational priorities varied considerably. For the employees, the appraisal system provided an important route to gaining feedback on their performance and reviewing progress in relation to previously agreed targets. From the appraisers' point of view, it provided an opportunity to relate the emplyee needs and preferences to the project requirements, and so endeavour to identify discordant issues.

Having presented the AMO analysis of the case study findings, the following discussion elaborates on the themes identified above and develops a cross analysis of the key issues highlighted as significant for the different sub-units. Some potential solutions are considered.

\section{Discussion}

The organisational strategic priorities, operational project requirements and individual employee needs and preferences have highlighted many areas of mutual consensus, as well as points of serious conflict. All three levels agree on the job challenge/ job autonomy and work-life balance aspects of motivation, and communications and employee involvement elements of opportunity. This is an excellent basis for high performance working given that many other aspects of SHRM rely on solid foundations in these areas. There are further areas of harmony between the strategic priorities and employee views (such as induction and training and development under ability, and careers and pay under motivation) and also few that connect the project level to employee views (for example teamworking under opportunity). Overall, it seems that in many respects it is the project level that forms the missing link in delivering the organisational strategic intentions to the individual employees. This is particularly true in 
terms of ability (recruitment and selection and training and development) and motivation (career development, pay and job security).

\section{Applicability of the AMO model to the case study findings}

From the above summary it is evident that all of the high performance HR policies/ practices central to the AMO model are relevant to the case study organisation. However, it is somewhat surprising to note that although 'ability', in terms of the availability of the appropriate staff with the right skills, is clearly one of the key concerns for operational success of the organisation, i.e. project delivery, the interview findings indicate much higher interest to recruitment and selection and training and development activities on behalf of the employees and senior management than the project level. Both of these HR considerations (recruitment and selection and training and development) are crucial for effective delivery of the strategic intent of the organisation, which is in line with high commitment management, and thus the AMO, "... we have placed the management of people at a strategic level...". However, conceptually, the application of the AMO model may need adjusting in terms of the relationships between ability and the team [project] level. It seems that holistically, although ability is crucial to project delivery (the central unit of production in construction work), the key concern for recruitment and selection is held at higher level, the senior management, and individual employees share their commitment with the organisational targets for continuous improvement. Working at a project level seems confer the position of 'recipient' that benefits from the results and outcomes of a wider organisational process and individual employee preference for development. Alternatively it may be that project management needs to play a more proactive role in shaping these aspects of SHRM.

The key issues in motivation were on the one hand a notable lack of project level concern for job security and on the other hand the all encompassing importance placed on job challenge/ autonomy and work-life balance. The proposition that motivation is 
intrinsically linked to the individual employee holds true, although senior managers saw the wider implications to the business, such as financial turnover, repeat business, enhanced marketing and business development opportunities and corporate image. This supports the application of AMO to the case study setting. As a framework for analysis, it has facilitated the identification of areas for improvement, such as job security. The AMO has also helped to highlight crucial areas of importance, such as job challenge/ autonomy and work-life balance. It is imperative that close attention is paid to these issues despite current success, as if they are managed inappropriately they are issues that could potentially lead to severe problems.

Finally, in relation to opportunity, where there was a consensus between the organisational, project and employee levels in relation to communications and employee involvement, significant differences came to light with regards to teamwork and appraisals. Overall it is clear that factors grouped under opportunity relate to organisational variables and specifically the processes and systems in place. This further supports the application of AMO model to the case study organisation. As with motivation above, the framework has helped to identify areas of importance and consensus as well as issues where improvements are required. These form the key strengths and weaknesses for the organisation at the centre of the discussion below.

\section{Some key issues}

From the above discussion first on the compatibility and conflicts between the employee needs and preferences, project requirements and organisational priorities, and then on the applicability of the AMO model to the case study findings, several strengths, weaknesses and key issues arise. This final section summarises these considering some potential solutions to the problem areas. 


\section{Strengths}

The strengths in the management style, policy and practices of the case study organisation clearly lie in the friendly organisational culture, which is transparent from the organisational statement of values through to the underlying principles of motivation and opportunity and employee understanding of the organisational commitment to their development (ability). Employee involvement and empowerment are key elements in the informal culture, which also encourages and facilitates active two-way communications throughout the organisation and beyond [externally]. Teamwork is inherent part of construction work and seen as one of the major factors in success.

\section{Weaknesses}

The weaknesses identified from the findings include ability: recruitment and selection and training and development (particularly at project level), job security (motivation) and appraisals (opportunity). As suggested above, improvements in 'ability' could be achieved by more active involvement of project level management. The devolvement of the SHRM responsibilities from senior managers to divisions needs to incorporate these variables into the day-to-day operational priorities and thus, encourage project ownership and commitment to effective induction (as well as other areas of recruitment and selection) and long-term staff and organisational development. In terms of job security, again, increased attention on behalf of the project management staff to the long-term commitment issues could provide significant improvements in the perception of high demand employees and other staff. The well established organisational communication mechanisms are ideally placed to support this development. For example, the regular team briefings could include information on forthcoming projects as well as current developments in the organisation and project managers input could prove valuable addition to senior managers' human resource planning activities. Appraisal is another useful communications channel, provided that this is clearly organised and implemented throughout the company. Currently appraisals are serving a mix of purposes, which differ between all sub-units. A uniform structure is essential to informative and successful appraisal interview session, however different needs the 
outputs of the process may serve. Here senior managers attention to long-term planning is useful as well as is the project managers performance monitoring and employees focus on feedback. The same set of data can indeed usefully be fed into different decision-making and management functions, however, as noted above the overall aim(s) and objectives of the meeting and wider process should be clear and consistent throughout the sub-units.

\section{Specific challenges: job challenge/ autonomy and work-life balance}

The job challenge/ autonomy and work-life balance variables (under motivation) were factors that all three sub-units (employees, project and organisational management) highlighted as crucial for effective resourcing decision-making. These form specific challenges for the organisation since there are cross cutting themes that the areas touch on. Although closely linked to employee involvement (opportunity), the company's emphasis on job challenge and autonomy had resulted in problems, such as increased employee expectations and stress (see Raidén et al, 2004). These problems derived from the specific organisational priority related to job security (motivation) to stabilise/ increase financial turnover. As shown in the organisational figures, this was achieved via the period of rapid growth 2000-2002 and more stable development 2002-2004 (it is recognised that the recent industry 'boom' may have contributed to the increase in the organisation's workload and resulting growth). Nevertheless, challenge remained to maintain this level of improvement since the success had clearly also resulted in problems. Managers attempted to deal with the increasing employee expectations by open career development discussions but the sustainability of long-term satisfaction was becoming uncertain. Stress was managed in collaboration with the externally facilitated employee assistance programme and organisational work-life balance initiatives, demotions and careful team deployment decision-making. All the above were reactive measures and managers clearly need to establish proactive channels for dealing with such problems. 
Some stress related problems arose from the training and development (ability) agenda where new positions proved too steep a learning curve for some individuals or where family life was compromised with training and development requirements. Increasing training and development activities, particularly those working toward recognised qualifications, naturally demand an increased work related input from the employee, commonly outside working hours. This is despite organisational support systems such as day-release-courses and on-the-job development. Generally this was not seen a substantial problem since many of the employees involved in intensive training placed high priority on qualifying and progression opportunities rather than time with family/ friends. However, all respondents saw this as a short-term solution and clearly indicated that in the long-term such time commitments would need to reduce. This also applied to travel, where junior members of staff had joined the company because of the possibilities for travel, a desire which declined as they took on familial responsibilities. Again, as with many of the weaknesses in the organisation, the strengths identified above are ideally placed to support the management of work-life balance.

\section{Conclusions}

This paper has considered the "People and Performance" model AMO (Boxall and Purcell, 2003: 20), as a route to performance improvement within a case study organisation. This analysis highlighted areas of consensus, as well as mismatch, between the employee and managerial views. However, most importantly, it was found that the project level was often the missing link in delivering the strategic intentions of the organisation to employee level. The strengths of the organisation go far in supporting the development of the weaker SHRM practices in the case study organisation. The challenge for the organisation given the constraints of the existing labour market is to maintain their high level prioritisation of SHRM if the company is to remain an employer of choice. Because project management forms the missing link between the organisational strategic intentions and individual employee needs and preferences, 
within a climate where SHRM responsibilities are devolved to operational management, the current form of operations is clearly not sustainable. It requires a structured resourcing framework to ensure the maximum benefits for the projects, employees' individual development and the organisation a whole. Whilst some areas of internal fit between operations and HR are apparent (job challenge/ job autonomy and work-life balance in terms of motivation and communication and employee involvement in terms of opportunity), the mismatch in relation to training and development (ability) and careers (motivation) is potentially costly and damaging to employee motivation and commitment and thus performance.

A more strategic employee resourcing framework could provide the tool for engaging the project level more appropriately in the balancing act which considers the individual employee needs and preferences, operational project requirements and organisational strategic priorities in a way that secures ability, motivation and opportunity at all levels. This framework would need to integrate the central employee resourcing activities (recruitment and selection, career development, teamworking and appraisal) with training and development and employee involvement elements of SHRM. This would allow for line management interaction with HR and senior management in ensuring effective delivery of the organisational strategic intent to the operational phases of project management. There is a need for further research, however, both to verify the results of this case study and to develop the suggested framework for improvement. Continued collaboration with the case study organisation is likely to prove favourable. To date the company has enjoyed the benefits of a detailed analysis of their people management practices, which has clearly revealed strengths and weaknesses in their approach.

\section{References}

Armstrong, M. and Baron, A. (2002) Strategic HRM: the key to improved business performance, London: CIPD

Bazeley, P. and Richards, L. (2000) The NVivo ${ }^{\circledR}$ qualitative project book, London: SAGE 
Boxall, P. (1998) Achieving competitive advantage through human resource strategy: towards a theory of industry dynamics. Human Resource Management Review, 8(3), 265-288

Boxall, P. and Steeneveld, M. (1999) Human Resource Strategy and Competitive Advantage: A Longitudinal Study of Engineering Consultancies. Journal of Management Studies, 36(4), 443-463

Boxall, P. (2003) HR strategy and competitive advantage in the service sector. Human Resource Management Journal, 13(3), 5-20

Boxall, P. and Purcell, J. (2003) Strategy and human resource management, London: Palgrave

Boyatzis, R.E. (1998) Transforming qualitative information: thematic analysis and code development, Thousand Oaks, CA: SAGE

Burgess, R.G. (1988) Studies in qualitative methodology, a research annual, conducting qualitative research, London: Jai Press

CITB (2003) Bridging the gap, http://www.citb.co.uk/research/reports/btg-emid/indexnonflash.html (accessed 23rd September 2003)

Dainty, A.R.J., Bagilhole, B.M. and Neale, R.H. (2000) The compatibility of construction companies' human resource development policies with employee career expectations. Engineering, Construction and Architectural Management, 7(2), 169178

Dainty, A.R.J., Bryman, A. and Price, A. (2002a) Empowerment within the UK construction sector. Leadership and Organisational Development Journal, 23(6), 333-342

Den Hartog, D.N. and Verburg, R.M. (2004) High performance work systems, organisational culture and firm effectiveness. Human Resource Management Journal, 14(1), 55-78

Donmoyer, R. (2000) Generalizability and the single-case study, In Gomm, R. et al (eds.) Case study method, London: SAGE, 45-68

Druker, J. and White, G. (1995) Misunderstood and undervalued? Personnel Management in Construction. Human Resource Management Journal, 5(3), 77-91

Druker, J., White, G., Hegewisch, A. and Mayne, L. (1996) Between hard and soft HRM: human resource management in the construction industry. Construction Management and Economics, 14, 405-416

DTI (2002) The state of the construction industry report, UK. http://www.dti.gov.uk/construction/stats/soi/soireport.htm (accessed 14th December 2005)

DTI (2005) Construction statistics annual, UK. http://www.dti.gov.uk/construction/stats/constat2005.pdf (accessed 14th December 2005)

Eckstein, H. (2000) Case study and theory in political science, In Gomm, R. et al (eds.) Case study method, London: SAGE, 119-164

Egan, J. (1998) Rethinking construction. Report from the Construction Task Force, UK, http://www.construction.detr.gov.uk/cis/rethink/index.htm (accessed $20^{\text {th }}$ January 2000)

Gomm, R., Hammersley, M. and Foster, P. (2000) Case study method. London: SAGE

Huselid, M.A. (1995) The impact of human resource management practices on turnover, productivity, and corporate financial performance. Academy of Management Journal, 38(3), 635-672 
Hutchinson, S., Purcell, J. and Kinnie, N. (2000) Evolving high commitment management and the experience of the RAC call centre. Human Resource Management Journal, 10(1), 63-78

Ichniowski, C., Kochan, T.A., Levine, D., Olson, C. and Strauss, G. (1996) What works at work: overview and assessment. Industrial Relations, 35(3), 299-333

Liao, Y. (2005) Business strategy and performance: the role of human resource management control. Personnel Review, 34(3), 294-309

Loosemore, M., Dainty, A. and Lingard, H. (2003) Human resource management in construction projects, strategic and operational approaches. London: Spon Press

Lähteenmäki, S., Storey, J. and Vanhala, S. (1998) HRM and company performance: the use of measurement and the influence of economic cycles. Human Resource Management Journal, 8(2), 51-65

Mabey, C., Salaman, G. and Storey, J. (1998) Strategic human resource management, $2^{\text {nd }}$ ed. Oxford: Blackwell Business

Marchington, M., Carroll, M. and Boxall, P. (2003) Labour scarcity and the survival of small firms: a resource-based view of the road haulage industry. Human Resource Management Journal, 13(4), 5-22

MacDuffie, J.P. (1995) Human resource bundles and manufacturing performance: organizational logic and flexible production systems in the world auto industry. Industrial and Labor Relations Review, 48(2), 197-221

Miles, M.B. and Huberman, A.M. (1994) Qualitative data analysis, $2^{\text {nd }}$ ed. Thousand Oaks, CA: SAGE

Mitchell, J.C. (2000) Case and situation analysis, In Gomm, R. et al (eds.) Case study method, London: SAGE, 165-186

Nesan, L.J. and Holt, G. (2002) Assessment of organisational involvement in implementing empowerment. Integrated Manufacturing Systems, 13(4), 201-211

Patton, E. and Appelbaum, S.H. (2003) The case for case studies in management research. Management Research News, 26(5), 60-71

Pfeffer, J. (1994) Competitive advantage through people. Boston: Harvard Business School Press

Platt, J. (1988) What can case studies do? In Burgess, R.G. (ed.) Studies in qualitative methodology, a research annual, conducting qualitative research, London: Jai Press, 1-23

Purcell, J. (1999) Best practice and best fit: chimera or cul-de-sac? Human Resource Management Journal, 9(3), 26-41

Purcell, J., Kinnie, N., Hutchinson, S., Rayton, B. and Swart, J. (2003) Understanding the people and performance link: unlocking the black box. London: CIPD

Raidén, A.B., Dainty, A.R.J. and Neale, R.H. (2004) Current barriers and possible solutions to effective project team formation and deployment within a large construction organisation. International Journal of Project Management, 22(4), 309-316

Raidén, A.B. Dainty, A.R.J. and Neale, R.H. (2005) Good Practice People Management through Human Resource Information Systems (HRISs), CIB Joint Symposium, Helsinki, Finland, 13-16 June

Schofield, J.W. (2000) Increasing the generalizability of qualitative research, In Gomm, R. et al (eds.) Case study method, London: SAGE, 69-97

Scholz, R.W. and Tietje, O. (2002) Embedded case study methods: integrating qualitative and quantitative knowledge. Thousand Oaks, CA: SAGE 
Smithers, G. and Walker, D. (2000) The effect of the workplace on motivation and demotivation of construction professionals. Construction Management and Economics, 18, 833-841

Strategic Forum for Construction (2002) Accelerating change. London: Rethinking Construction

Taylor, S. (2002) The employee retention handbook. London: CIPD

Wood, S. and de Menezes, L. (1998) High commitment management in the UK:

evidence from the workplace industrial relations survey and employers' manpower and skills practices survey. Human Relations, 51(4), 485-515

Yin, R.K. (2003) Case study research, design and methods ( $3^{\text {rd }}$ ed). London: SAGE

26 
Table 1: Summary of project deployment priorities overall, by job role (examples of project managers, QSs, engineers and foremen) and individual employee (examples A and B)

\begin{tabular}{|c|c|c|c|c|c|c|c|c|c|}
\hline & 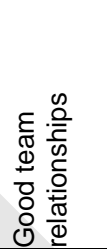 & 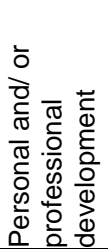 & 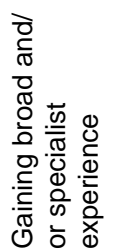 & 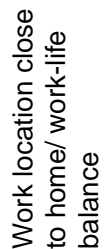 & 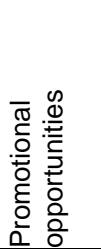 & 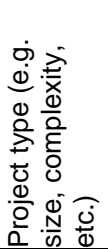 & 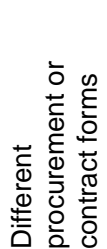 & 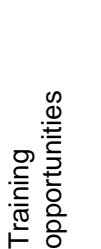 & 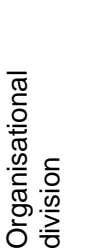 \\
\hline $\begin{array}{c}\text { Overall } \\
\text { (value/ \%) }\end{array}$ & $\begin{array}{c}1 \\
(195 / \\
68.66)\end{array}$ & $\begin{array}{c}2 \\
(165 / \\
58.09)\end{array}$ & $\begin{array}{c}3 \\
(141 / \\
56.85)\end{array}$ & $\begin{array}{c}4 \\
(129 / \\
52.01)\end{array}$ & $\begin{array}{c}5 \\
(127 / \\
51.20)\end{array}$ & $\begin{array}{c}6 \\
(116 / \\
46.77)\end{array}$ & $\begin{array}{c}7 \\
(107 / \\
43.14)\end{array}$ & $\begin{array}{c}8 \\
(101 / \\
40.72)\end{array}$ & $\begin{array}{c}9 \\
(28 / \\
11.29)\end{array}$ \\
\hline Proj. mngt & 1 & 3 & 6 & 5 & 4 & 2 & 7 & 8 & 9 \\
\hline QSs & 1 & 3 & 2 & 5 & 4 & 8 & 7 & 6 & 9 \\
\hline Engineers & $=5$ & 1 & $=2$ & $=5$ & $=5$ & $=5$ & $=2$ & 4 & 9 \\
\hline Foremen & 2 & 5 & 7 & 1 & $=8$ & $=3$ & 6 & $=3$ & $=8$ \\
\hline Empl. A & 5 & 2 & 4 & 1 & 3 & 7 & 9 & 6 & 8 \\
\hline Empl. B & 1 & $=2$ & $=2$ & 7 & 8 & 5 & 6 & 9 & $=2$ \\
\hline
\end{tabular}


Table 2: Employee needs and preferences ${ }^{3}$, project requirements ${ }^{4}$ and organisational strategic priorities ${ }^{5}$ in relation to ability (within the AMO model ${ }^{1}$ ) and corresponding HR policies/ practices ${ }^{2}$

\begin{tabular}{|c|c|c|c|c|}
\hline${ }^{1}$ AMO & $\begin{array}{l}{ }^{2} \text { HR policyl } \\
\text { practice }\end{array}$ & $\begin{array}{l}{ }^{3} \text { Employee needs and } \\
\text { preferences }\end{array}$ & ${ }^{4}$ Project requirements & $\begin{array}{l}{ }^{5} \text { Organisational } \\
\text { priorities }\end{array}$ \\
\hline \multirow[t]{2}{*}{ Ability } & $\begin{array}{l}\text { Recruitment and } \\
\text { selection }\end{array}$ & Induction & & $\begin{array}{l}\text { Induction } \\
\text { Balance between agency } \\
\text { and permanent staff } \\
\text { ratio }\end{array}$ \\
\hline & $\begin{array}{l}\text { Training and } \\
\text { development }\end{array}$ & $\begin{array}{l}\text { Personal (and } \\
\text { organisational) } \\
\text { development } \\
\text { Graduate development } \\
\text { Training } \\
\text { Work type; Procurement } \\
\text { methods }\end{array}$ & Cross project learning & $\begin{array}{l}\text { Organisational (and } \\
\text { employee) } \\
\text { development via } \\
\text { training plan - } \\
\text { improve weaknesses } \\
\text { Graduate development; } \\
\text { Taking on trainees } \\
\text { Shifting emphasis from } \\
\text { civil engineering focus } \\
\text { toward building }\end{array}$ \\
\hline
\end{tabular}


Table 3: Employee needs and preferences ${ }^{3}$, project requirements ${ }^{4}$ and organisational strategic priorities ${ }^{5}$ in relation to motivation (within the AMO model ${ }^{1}$ ) and corresponding HR policies/ practices ${ }^{2}$

\begin{tabular}{|c|c|c|c|c|}
\hline${ }^{1}$ AMO & $\begin{array}{l}{ }^{2} \text { HR policyl } \\
\text { practice }\end{array}$ & $\begin{array}{l}{ }^{3} \text { Employee needs and } \\
\text { preferences }\end{array}$ & ${ }^{4}$ Project requirements & $\begin{array}{l}{ }^{5} \text { Organisational } \\
\text { priorities }\end{array}$ \\
\hline \multirow[t]{5}{*}{ Motivation } & $\begin{array}{l}\text { Career } \\
\text { development }\end{array}$ & $\begin{array}{l}\text { Career development } \\
\text { Progression; Promotion } \\
\text { Horizontal moves }\end{array}$ & & $\begin{array}{l}\text { Career development } \\
\text { (achievable } \\
\text { aspirations) } \\
\text { Succession planning; } \\
\text { Transparent } \\
\text { progression } \\
\text { opportunities for } \\
\text { employees (good } \\
\text { retention tool) } \\
\text { Fast track progression }\end{array}$ \\
\hline & Pay & $\begin{array}{l}\text { Benefit preferences (e.g. } \\
\text { car) } \\
\text { Pay }\end{array}$ & & $\begin{array}{l}\text { Employee pay - when } \\
\text { right strong retention } \\
\text { factor } \\
\text { Equal terms and } \\
\text { conditions for staff }\end{array}$ \\
\hline & Job security & $\begin{array}{l}\text { Discussion on } \\
\text { (organisational and } \\
\text { employee) } \\
\text { expectations }\end{array}$ & & $\begin{array}{l}\text { Manageable employee } \\
\text { turnover } \\
\text { Stabilise/ increase } \\
\quad \text { turnover }(£) \\
\text { Repeat business } \\
\text { Broaden business in } \\
\text { strategic terms } \\
\text { Marketing and } \\
\text { developing business }\end{array}$ \\
\hline & $\begin{array}{l}\text { Job challenge/ } \\
\text { job autonomy }\end{array}$ & $\begin{array}{l}\text { Nature of work } \\
\text { Role and responsibilities } \\
\text { Job enrichment/ } \\
\quad \text { enlargement }\end{array}$ & $\begin{array}{l}\text { Clear roles and } \\
\text { responsibilities: } \\
\text { people not chasing } \\
\text { the same ball }\end{array}$ & $\begin{array}{l}\text { Job satisfaction and } \\
\text { enjoyment } \\
\text { Job rotation }\end{array}$ \\
\hline & $\begin{array}{l}\text { Work-life } \\
\text { balance }\end{array}$ & $\begin{array}{l}\text { Long hours (and working } \\
\text { weekends); Overtime } \\
\text { Work-life balance; } \\
\text { Holiday } \\
\text { Travel; Project (work) } \\
\text { location; Staying } \\
\text { (lodging) away } \\
\text { Office location (and } \\
\text { move of offices) } \\
\text { Health problems }\end{array}$ & $\begin{array}{l}\text { Minimum travel - can } \\
\text { affect performance/ } \\
\text { employee health, } \\
\text { facilitates retention }\end{array}$ & $\begin{array}{l}\text { Work-life balance (good } \\
\text { employer scenario) - } \\
\text { facilitates retention } \\
\text { Workload }\end{array}$ \\
\hline
\end{tabular}


Table 4: Employee needs and preferences ${ }^{3}$, project requirements ${ }^{4}$ and organisational strategic priorities ${ }^{5}$ in relation to opportunity (within the AMO model ${ }^{1}$ ) and corresponding HR policies/ practices ${ }^{2}$

\begin{tabular}{|c|c|c|c|c|}
\hline${ }^{1} \mathrm{AMO}$ & $\begin{array}{l}{ }^{2} \text { HR policyl } \\
\text { practice }\end{array}$ & $\begin{array}{l}{ }^{3} \text { Employee needs and } \\
\text { preferences }\end{array}$ & ${ }^{4}$ Project requirements & $\begin{array}{l}{ }^{5} \text { Organisational } \\
\text { priorities }\end{array}$ \\
\hline \multirow[t]{4}{*}{ Opportunity } & Communication & $\begin{array}{l}\text { Communication; } \\
\text { Communication on } \\
\text { wider organisational } \\
\text { issues } \\
\text { Comprehensive range of } \\
\text { info on projects }\end{array}$ & $\begin{array}{l}\text { Effective communication } \\
\text { both internally \& } \\
\text { externally } \\
\text { Effective information } \\
\text { flows } \\
\text { No controversial } \\
\text { correspondence }\end{array}$ & $\begin{array}{l}\text { Two-way communication; } \\
\text { Open door policy; } \\
\text { Short and direct links } \\
\text { through management } \\
\text { structure } \\
\text { Managers approachable } \\
\text { and accessible } \\
\text { Integration within larger } \\
\text { group (following the } \\
\text { merger) }\end{array}$ \\
\hline & $\begin{array}{l}\text { Employee } \\
\text { involvement }\end{array}$ & $\begin{array}{l}\text { Employee involvement } \\
\text { Recognition of } \\
\text { contribution to } \\
\text { organisation; Interest } \\
\text { from top } \\
\text { management/ head } \\
\text { office } \\
\text { Organisational culture } \\
\text { Organisational structure }\end{array}$ & $\begin{array}{l}\text { Tackle problems } \\
\text { effectively } \\
\text { Situations be solved at } \\
\text { middle management } \\
\text { tiers }\end{array}$ & $\begin{array}{l}\text { Empowerment, people } \\
\text { feel they have a } \\
\text { contribution } \\
\text { Employees to get } \\
\text { recognition from } \\
\text { management and } \\
\text { colleagues } \\
\text { Organisational culture } \\
\text { and spirit; Maintaining } \\
\text { the culture; Trust; No } \\
\text { blame culture; } \\
\text { Openness; Communal } \\
\text { breaks; Individualistic } \\
\text { management style; } \\
\text { Delegation }\end{array}$ \\
\hline & Teamworking & $\begin{array}{l}\text { Team member selection; } \\
\text { Team redeployment } \\
\text { (kept together) } \\
\text { Interdepartmental co- } \\
\text { operation; Moving } \\
\text { between divisions/ } \\
\text { departments } \\
\text { Recognition of individual } \\
\text { qualities; Best use of } \\
\text { skills/ talents } \\
\text { Project (deployment) } \\
\text { opportunities; } \\
\text { Employee suitability to } \\
\text { project and } \\
\text { specialisation in } \\
\text { project allocation } \\
\text { Team spirit; Team } \\
\text { integration and co- } \\
\text { ordination }\end{array}$ & $\begin{array}{l}\text { Team selection: } \\
\text { Balanced team, blend } \\
\text { of individuals, mix of } \\
\text { personalities; Good/ } \\
\text { strong leadership: } \\
\text { right leader (e.g. } \\
\text { project manager) on } \\
\text { team } \\
\text { Manager to know his/ her } \\
\text { staff, their abilities and } \\
\text { needs (e.g. training } \\
\text { needs) } \\
\text { Make best use of } \\
\text { employee skills, } \\
\text { talents and abilities } \\
\text { Team relationships } \\
\text { Team spirit; No attitude } \\
\text { problem; Singularity } \\
\text { and focus } \\
\text { Disruptive influences } \\
\text { removed fast }\end{array}$ & Partnering \\
\hline & Appraisal & $\begin{array}{l}\text { Feedback on } \\
\text { performance; } \\
\text { Feedback on progress } \\
\text { Appraisal; Progress } \\
\text { review }\end{array}$ & $\begin{array}{l}\text { Project performance: } \\
\text { Profitability; Efficiency } \\
\text { of site; Health and } \\
\text { safety; Quality; Time } \\
\text { Give value for money; } \\
\text { Commercial aspects } \\
\text { (surveying) } \\
\text { Team-client } \\
\text { relationships (highly } \\
\text { important!); } \\
\text { Client satisfaction; Client } \\
\text { preferences; Client } \\
\text { involvement } \\
\text { Subcontractor } \\
\text { relationships; } \\
\text { Subcontractor } \\
\text { performance }\end{array}$ & $\begin{array}{l}\text { Longer-term planning } \\
\text { Continuous } \\
\text { improvement; } \\
\text { Managing change; } \\
\text { Flexibility } \\
\text { Work within legislation/ } \\
\text { regulations (e.g. } \\
\text { TUPE); Quality } \\
\text { assurance }\end{array}$ \\
\hline
\end{tabular}

